\title{
Demand of Using Sharing-Based Transportation Services in Indonesia: Does Socio-Religious Preference Matter?
}

\author{
Dea Larasati \\ Faculty of Economics and Business \\ Universitas Indonesia \\ Depok, Indonesia \\ dea.larasati27@gmail.com
}

\author{
Rahmatina Awaliah Kasri \\ Faculty of Economics and Business, \\ Universitas Indonesia \\ Depok, Indonesia \\ unirahma@gmail.com
}

\begin{abstract}
Sharing economy is an emerging economic platform believed to bring a major change due to its potential to resolve market inefficiency issues. The concept is presumably related to the Islamic microeconomic concepts, particularly huquq (multi interest) and maslahah (greatest benefit). Therefore, the study aims to determine the demand of sharing-based transportation services in Indonesia and subsequently examine the influence of socioreligious preference (constructed based the aforementioned Islamic consumer values) on such demand. This study uses quantitative approach and collects primary data from 1209 respondents. The data obtained are analyzed by using Factor Analysis and inferential statistics. Preliminary result indicates trust, service quality and tariff as key factors influencing demand for online transportation services. It is also found that there is a different preference between users in religious group and less religious groups. More religious consumers are more concerned about environment compared to the counterpart. However, in other aspects, no significant difference is found between the two groups. Overall, the results of this study are expected to enrich the literature in sharing-based economy studies and become input for sharing-based transportation service providers, government, academics and other related parties.
\end{abstract}

Keywords - sharing economy, sharing-based transportation, online transportation, huquq, maslahah, Islamic consumer behaviour, Islamic microeconomics.

\section{INTRODUCTION}

Sharing economy is an economic model in which consumers use online devices for collaboration in the ownership, rent, share, and exchange of goods and services (Bucher et al, 2016, in Nguyen 2016) such as in transportation. Online transportation is ride-hailing or ride-sharing business model based on mobile apps, in which users can easily find a private transportation to take them to the destination at a transparent and relatively inexpensive price. The emergence of online transportation is welcomed by urban communities who have long been looking forward to affordable, quality, and accessible transportation services [2]. In Indonesia, popular providers of sharing-based transportation services - or better known as online transportation - are Gojek, Uber, and Grab
[11]. As the business model is relatively new in Indonesia, it is notable that very few studies attempt to analyse the demand of such service.

Conceptually, sharing economy appears to be in line with Islamic economics values, particularly huquq and maslahah which are the main concepts in consumer behaviour from Islamic perspective [4]. Huquq is a concept in which individuals have the right for themselves as well as the obligation to others. In other words, this concept suggests that basically people have multi-interests; they do not only consider their own interests but also consider the benefits for others. Meanwhile, maslahah is a concept which suggests that an individual acts based on a calculation if it brings benefit or bad for themselves and others. As such, according to Islamic perspective, a Muslim must behave in a way that provides greatest benefits to all [4]. These concepts are in line with the sharing economy concepts as both rely on sharing of resources through various modes of collaborative consumptions to achieve greatest benefits to the society.

Based on the views above, the study aims to determine the demand of sharing-based transportation services in Indonesia and subsequently examine the influence of socioreligious preference (constructed based the aforementioned Islamic consumer values) on such demand. To achieve the objectives, this study uses quantitative approach. It collects primary data from 1209 users of sharing-based transportation in Indonesia and employs Factor Analysis to derive the determinants of demand for the sharing-based transportation services. It also uses inferential statistics to examine the influence of socio-religious preference on the service demand.

\section{LITERATURE REVIEW}

This section reviews a number of relevant literature, including sharing economy and consumer behavior in Islamic perspective. The connections of the two concepts are also explored. Finally, it also discusses some empirical studies regarding the sharing-based transportation services demand which becomes the basis for the empirical model in the paper.

\subsection{Sharing Economy}

Sharing economy, collaborative consumption, and peerto-peer economy become quite popular terms in a few years. Nasscom (2015) defined sharing economy as a socio-economic system that was formed due to sharing of resources and manpower, as well as sharing the creation, production, 
exchange and consumption of goods and services among different communities and organizations. The emergence of sharing economy platform is primarily driven by technological advances and high demand in the market. This platform allows a peer-to-peer transaction on an unprecedented speed, which potentially minimizes the transaction costs. At the same time, sharing economy platform provides greater choice to users and often at a lower price [2]. Besides setting price as the main attraction, sharing economy platform also emphasizes ethical, social, and environmental values.

In conclusion, the definition of sharing economy is the concept of resources-sharing through various modes of collaborative consumptions to achieve greatest benefits to society. To this end, it appears that the concept is similar with values and concepts of Islamic economic such as huquq (multi interest) and maslahah (greates social benefits). These concepts will be elaborated in the next sub-section.

\subsection{Consumer Behaviour in Islamic Economics}

As conventional economics has a basic framework of consumer or individuals behaviours, Islamic economy also has its own micro-foundations. As outlined in Furqani (2015), the microfondations concepts are related to basic relationships (self interest vs. Huquq), motive (utility maximization vs. maslahah) and main characters of economic men (rationality vs. taqwa).

\section{a. Basic relationship: self-interest vs. huquq}

Self-interest has the sense that human beings are autonomous/atomistic and self-centered. However, in Islam, the concept of huquq is known. Huquq is a concept in which individuals have the right for themselves as well as the obligation to do to others. In other words, this concept suggests that basically people have multi-interests, that they are do only consider their own interests but also consider the benefits for others.

b. Relationship motive: utility maximization vs. maslahah

Maximization is one of the major postulates in economics. In Islam, a choice is taken on the basis of calculating whether a thing brings benefits or badness to oneself and others. Maslahah concept also covers benefits for humans and environment, where self-pleasure is not an absolute goal. According to Islamic perspective, a Muslim must behave in a way that provides greatest benefits to all.

c. The main character of economic men: rationality vs. taqwa

Rationality is a basic trait in economics that explains human character, behaviour patterns and to predict the outcome of such actions in the future. Islamic economics explaines the rational behavior of Islamic man is "Islamic rationality", or sometimes called as taqwa. Taqwa drives individuals to have the awareness that will preserve and protect them from actions that can cause damage (mafsadah) against other people and the environment.

\subsection{Sharing Economy Linkages with Islamic Economics}

The Islamic micro-foundations explained above are in line with the concept of sharing economy. The development of sharing economy has changed people's consumption patterns, from owning something to sharing something. Thus, in sharing economy, it is important to have access to these goods and spirit of mutual help [7]. Moreover, millennials as primary users of sharing economy have accustomed to bartering, sharing and buying goods that have been used. Millennials say to more care about others and be less interested in material things and consumerism lifestyle [6]. This is in line with the concepts of huquq and maslahah in Islamic economics that an individual acts by not only focusing on their own interests, but also considering the benefits and impacts for others. All in all, the concepts appear to be in harmony as they rely on sharing of resources through various modes of collaborative consumptions to achieve greatest benefits to society.

\subsection{Demand and Satisfaction for Sharing-based Transportation Services}

Several previous studies have analysed the demands of sharing-based transportation services. Mohlmann (2015) analysed factors influencing the choice of the sharing option. The results of the study indicated several determinants of using sharing-based transportation: community belonging, cost, familiarity, quality of service, trust, and utilities. Those determinants significantly affected users' satisfaction and the desire to reusing sharing option. Other study by Teubner, Timm, Hawlitschek, Florian, Gimpel, and Henner (2016) analysed the motives in using sharing economy. The study found that the factors encouraging the use of sharing transportation are ecological sustainability, cost advantages, and the expression of a modern lifestyle, variety and ubiquitous availability, sense of community belonging, social interactions, and altruistic enjoyment of helping others. These results are confirmed by the study of S. Yang, Y. Song, S. Chen. and X. Xia (2017), which suggested that confidence, safety benefits, social benefits positively influenced the commitment to use sharing economy.

In the context of Indonesia, few studies have attempted to determine the demand for certain types of sharing-based transportation services. This is not surprising since the online transportation services - with Gojek, Grab and Uber as the market leaders-- have just gained popularity in the country since 2015 when they started to use application in android mobile system. Among the few studies are Harish and Wardhana (2015), and Natyari and Pradana (2016). The former analysed the preference of consumers in using Go-Jek in Jakarta and found that practicality, tariff, speed, safety, trust and comfort are the main determinants for using the services. Similar findings, but speed, are also suggested by Natyari dan Pradana (2016) for the case of Uber in Bandung.

All in all, the literatures suggest a number of factors which potentially determine the demand of sharing-based transportation services; those are service quality, trust, comfort, tariff, speed, environment impact and trend affinity. The influence of the variables vary, depending on the country or case studied. However, so far, there is no empirical study done for the case of Indonesia as a country. Thus, this is the focus of the current research study.

\section{RESEARCH METHOD}

This section explains the model specification, the data and the analytical methods used in the study.

\subsection{Model Specification}

To construct the research model, a combination of the variables that have been tested in previous studies is used. In this study, there are six main independent variables which potentially determine the demand of sharing-based transportation services: service quality, trust, comfort, tariff, environment impact and trend affinity (see Figure 1). 
Figure 1 Research Model of Demand and Users' Satisfaction of Using Online Transportation in Indonesia

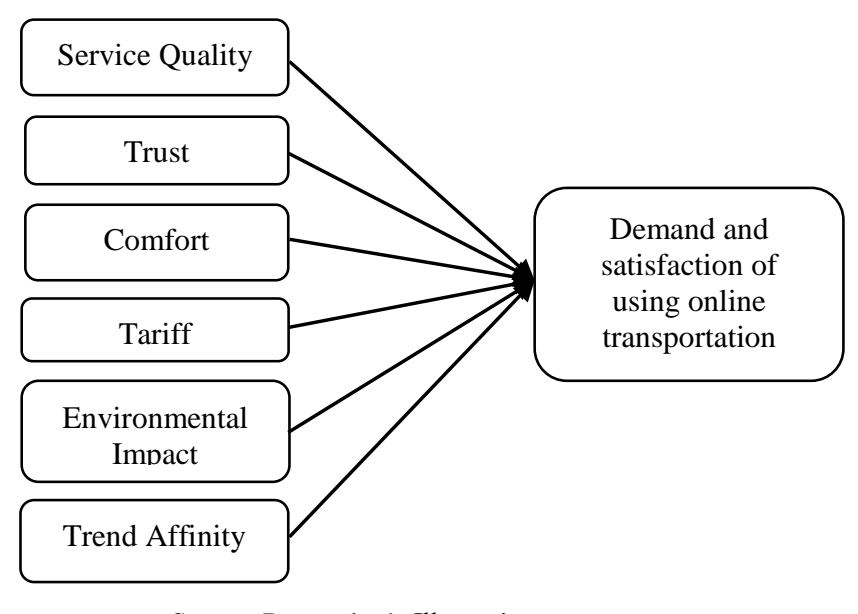

Source: Researcher's Illustration

The research also examines the consumers' socioreligious preferences and sees whether it influences the demand. The socio-religious preferences are consructed based on the modified Religious Orientation Scale (ROS) developed by Allport and Ross (1967). ROS is developed from the theory that there are motives behind one's religious behaviour: intrinsic and extrinsic motives. The extrinsic motive includes religion as a way to achieve self-serving, social support, comfort for all, and confidence; whereas the intrinsic motive is driven by the belief to enhance spiritual and deeper relationship with God [3]. This study argues that the former motive is similar to the value embodied by the concept of huquq and maslahah, since they emphasise on multi interests (particularly self-serving and social support) and social welfare. Meanwhile the latter seems to be in line with the concept of taqwa in Islam.

Based on the framework above, a questionnaire is constructed as the research instrument. The questionnaire consists of questions regarding profile, socio-religious preferences (i.e. quite religious and religious) and perception regarding the influence of the six aforementioned variables towards the demand for the online transportation. The perception of respondents are measured by using a six-point Likert scale.

\subsection{Data and Analytical Method}

This study uses primary data obtained by distributing the questionnaires through various social media and online channels. The social media and online channels are mainly used due to its effectiveness in reaching respondents from many places [8]; the area of study in this research covers all around Indonesia. Further, to be eligible as a respondent, one must have used the online-based transportation in the last three months. From the distribution of the questionnaires in May 2017, valid responses were obtained from 1209 respondents.

The primary data obtained is analysed by using descriptive statistics, factor analysis and inferential analysis. Descriptive statistics are statistics used to describe the tendency (mean, median, modus, dll) of data. Meanwhile, factor analysis is a method of analysis to process research data by identifying the basic variables or factors that explain the relationship pattern in a set of observation variables. Thus, it is employed to analyse the determinants of using sharing-based transportation services in Indonesia. Finally, the inferential statisctics utilized is the independent sample t-test which is aimed to see the difference in the demand between the quitereligious and religious groups [8].

\section{FINDINGS AND ANALYSIS}

This section discusses the findings and analyses of the study.

\subsection{Profile of Respondent}

Respondents in this study are dominated by women, whose number is twice the number of male respondents. In addition, most of the respondents are students $(63.35 \%)$, aged between $15-24$ years $(79.25 \%)$, not married $(83.7 \%)$, and have an average income of less than Rp 2 million per month (56\%). From this profile, it is revealed that most of the users of online transportation are low-income students (youth).

In terms of religion, most of the respondents are Muslims $(90.4 \%)$. The rest $(9.6 \%)$ are followers of religions other than Islam. Further, the respondents in this questionnaire are dominated by people living in Jakarta (30.76\%). Other domiciles vary from various cities in Indonesia such as Solo, Bali, Medan, Balikpapan, Manado, Palembang, Samarinda, Pekanbaru, Padang, Mataram, Demak, Jember, Banyuwangi, Tasikmalaya, Banjarmasin, Tegal, Sidoarjo, Lombok, Lamongan and Kediri.

\subsection{Demand and Satisfaction for using Sharing-Based Transportation Services}

Determinants for using sharing-based transportation services are analysed by using Factor Analysis. Prior to that, the Factor Analysis, KMO and Bartlett Test Sphericity are conducted to determine the feasibility of factor analysis; the correlation tests between independent variables are also performed for both groups. Afterwards, the factoring process and grouping factors are done. The results are as follow:

Table 1. KMO and Bartlett's Test Results

\begin{tabular}{|c|c|c|c|}
\hline & & $\begin{array}{c}\text { Quite } \\
\text { Religious } \\
\text { Group }\end{array}$ & $\begin{array}{l}\text { Religious } \\
\text { Group }\end{array}$ \\
\hline \multicolumn{2}{|c|}{$\begin{array}{l}\text { Kaiser-Meyer-Olkin Measure } \\
\text { of Sampling Adequacy. }\end{array}$} & 0,804 & 0,834 \\
\hline \multirow{3}{*}{$\begin{array}{l}\text { Bartlett's Test } \\
\text { of Sphericity }\end{array}$} & $\begin{array}{l}\text { Approx. Chi- } \\
\text { Square }\end{array}$ & 648,999 & 1387,541 \\
\hline & Df & 15 & 15 \\
\hline & Sig. & 0,000 & 0,000 \\
\hline
\end{tabular}

For quite-religious group, the KMO results show a value of 0.804 with a significance of 0.000 . Since the KMO score is above 0.5 and the significance is below 0.05 , the factors in this group can be further analysed with factor analysis. Religious group also shows KMO values above 0.5 , ie 0.834 , with significance less than 0.05 . Thus, similar to the former, the factors that exist in this group can be further analyzed by factor analysis.

\section{b. Anti Image Matrices}

After performing data processing with KMO and Bartlett Test Sphericity, the next step is to look at the correlation between independent variables that can be seen in Anti Image Matrices table through the value of Measure of Sampling Adequacy (MSA). The result shows that value of MSA (diagonal numbers on Anti Image Correlation) is more than 0.5. A similar result was found with respect to the religious groups. Thus, the value of each factor could be predicted and further analysed.

\section{c. Grouping Factors}


In the data processing using factor analysis, the next step to do is grouping factors. Grouping factors is done to determine each initial factor to enter the new factor that is formed. Grouping these factors is done by looking at the Component Matrix produced, as follows:

Table 2. Component Matrix

\begin{tabular}{|c|c|c|}
\hline \multirow{2}{*}{} & Quite-Religious & Religious \\
\cline { 2 - 3 } & Component & Component \\
\cline { 2 - 3 } & 1 & 1 \\
\hline Service quality &, 794 &, 761 \\
\hline Trust &, 812 &, 794 \\
\hline Comfort &, 751 &, 755 \\
\hline Tariff &, 709 &, 667 \\
\hline $\begin{array}{c}\text { Environmental } \\
\text { impact }\end{array}$ &, 343 &, 694 \\
\hline Trend affinity &, 704 &, 549 \\
\hline
\end{tabular}

Based on the results above, there are indications that five variables significantly affect the demand and satisfaction of the respondents within the Quite-Religious group, including confidence $(81.2 \%)$, service quality $(79.4 \%)$, convenience $(75.1 \%)$, tariff $(70.9 \%)$, and trend influence $(70.4 \%)$. Meanwhile, the environmental impact variable does not affect the satisfaction of Quite-Religious groups in using online transport.

Different results are shown by the Religious Group (see Table 4), in which there are six factors that significantly influence the satisfaction in using online transportation in Indonesia. They are trust $(79.4 \%)$, service quality $(6.18 \%)$, comfort $(75.5 \%)$, environmental impact $(69.4 \%)$, tariff $(66.7 \%)$, and trend influence $(54.9 \%)$. Thus, the six most dominant factors are confidence with the highest correlation value of 0.805 or $80.5 \%$.

Further, to see the differences between Quite-Religious groups and Religious groups in their preferences for using online transportation, descriptive statistics are calculated (see Table 3 ) and a series of t-statistics are perfomed (see Table 4). Of the six independent variables used, results of the descriptive statistics suggest the Religious group has higher average value than the other group. This implies that the former are more satisfied in all aspect as compared to the Quite-Religious group. This conclusion is confirmed by the t-test results which indicate that there is indeed a difference in service quality, trust, comfort, tariff, environmental impact and trend affinity between quite-religious group and religious group.

\begin{tabular}{|c|c|c|c|c|c|}
\hline \multirow{2}{*}{ Service quality } & $\begin{array}{c}\text { Socio-Religious } \\
\text { Preferences }\end{array}$ & $\mathrm{N}$ & mean & $\begin{array}{c}\text { Std. } \\
\text { deviation }\end{array}$ & $\begin{array}{c}\text { SE } \\
\text { Mean }\end{array}$ \\
\cline { 2 - 7 } & Religious & 838 & 5.1161 &, 53995 &, 01865 \\
\hline \multirow{2}{*}{ Trust } & Quite-Religious & 371 & 4.8349 &, 60616 & 03147 \\
\cline { 2 - 7 } & Religious & 838 & 4.7246 &, 70723 & 02443 \\
\cline { 2 - 7 } & Quite-Religious & 371 & 4.4380 &, 68566 &, 03560 \\
\hline
\end{tabular}

Table 3, cont.

\begin{tabular}{|c|c|c|c|c|c|}
\hline \multirow{2}{*}{ Comfort } & Religious & 838 & 4.7303 &, 69253 &, 02392 \\
\cline { 2 - 6 } & Quite-Religious & 371 & 4.3416 &, 68133 & 03537 \\
\hline \multirow{2}{*}{ Tariff } & Religious & 838 & 5.0952 &, 68236 & 02357 \\
\cline { 2 - 6 } & Quite-Religious & 371 & 4.8497 &, 71008 & 03687 \\
\hline \multirow{2}{*}{$\begin{array}{c}\text { Environmental } \\
\text { impact }\end{array}$} & Religious & 838 & 4.5904 &, 98235 & 03393 \\
\cline { 2 - 6 } & Quite-Religious & 371 & 4.3342 &, 86767 & 04505 \\
\hline \multirow{2}{*}{\begin{tabular}{c} 
Trend Affinity \\
\cline { 2 - 6 }
\end{tabular}} & Religious & 838 & 4.1354 & 1.01593 & 03509 \\
\cline { 2 - 6 } & Quite-Religious & 371 & 3.7864 &, 88131 &, 04576 \\
\hline
\end{tabular}

Table 4. Independent Samples Test

\begin{tabular}{|c|c|c|c|c|c|}
\hline \multirow{2}{*}{} & \multicolumn{5}{|c|}{ Table 4. Independent Samples Test } \\
\cline { 2 - 6 } & $\mathrm{T}$ & $\mathrm{df}$ & $\begin{array}{c}\text { Sig. (2- } \\
\text { tailed) }\end{array}$ & mean Diff & $\begin{array}{c}\text { Std. error } \\
\text { Diff }\end{array}$ \\
\hline $\begin{array}{c}\text { Service } \\
\text { quality }\end{array}$ & 7.685 & 640.663 &, 000 &, 28114 &, 03658 \\
\hline Trust & 6.560 & 1207 &, 000 &, 28664 &, 04369 \\
\hline $\begin{array}{c}\text { Comfort } \\
\text { Tariff }\end{array}$ & 9.044 & 1207 &, 000 &, 38867 &, 04297 \\
\hline $\begin{array}{c}\text { Environmental } \\
\text { impact }\end{array}$ & 4.330 & 1207 &, 000 &, 25616 &, 05916 \\
\hline Trend affinity & 5.731 & 1207 &, 000 &, 34905 &, 06090 \\
\hline
\end{tabular}

The general results above are quite similar from previous studies, including the studies of Harish \& Wardhana (2015) and Natyari \& Pradana (2016). Trust and comfort were found to be the most significant variables that influence the demand and satisfation of online transportation users in Indonesia. It can be argued that these two factors are the advantages offered by online transport as compared to conventional transportation. The built system allows passengers to identify the driver's identity; the sense of security of crime - which often occurs when using public transport - can be awakened. This sense of security creates a sense of comfort when driving.

The quality of service also shows a significant result in this study. This indicates that the online transport users assume that the easy access to mobile apps, the speed of the transport driver online waiting, speed and accuracy in delivering to the destination, as well as the practicality of the method of payment are the important factors affecting users' satisfaction. This result is in line with Mohlmann's research (2015), where service quality positively affected the satisfaction and reuse of sharing options. Widianti et al (2015) also stated that the quality of service affected the re-use of public transportation in Bandung, Medan, and Surabaya.

Tariffs were also found to be positively affecting the satisfaction of online transportation users, as found by Harish \& Wardhana (2015) and Natyari \& Pradana (2016). Cheaper rates, frequent promos, matching rates and tariff eligibility are the main attractions for people to use online transport in Indonesia. Meanwhile, the influence of trends is a less 
dominant factor in influencing consumer demand and satisfaction. These results are consistent with research done by Mohlmann (2015). This indicates that people using the platform of sharing economy, or in this case the transport line, not because of a growing trend, but due to the quality offered by the economic transportation of good quality and can meet the needs of the community.

Different results are shown by the environmental impact variables. This variable positively affects the Religious group, but does not have a significant relationship with the QuiteReligious group. The indicators in the environmental impact variable reflect that by using online transportation, users can save fuel, reduce air pollution and congestion, and reduce the use of private vehicles; thus making users feel satisfied in using online transportation. The outcome difference between the two groups of respondents in this variable indicates that the higher the socio-religious level of a community, the more they care about environmental sustainability. In previous studies, conflicting results were found. Mohlmann (2015) suggested that environmental impact does not affect the satisfaction and reuse of sharing options. However, Teubner, Timm, Hawlitschek, Florian, Gimpel, and Henner (2016) stated the opposite.

The difference between Quite-Religious group and Religious group has not touched by previous studies; the study argues that the difference might be related to the conditions of public transport in Indonesia and the characters of religious people in the country. In one hand, public transport services in Indonesia could be considered as relatively poor. This can be seen from the massive use of private vehicles, since most of the public transport services do not offer high standard of services, less comfortable and less safe compared to private transports. On the other hand, religious people in Indonesia tend to value high positive changes such as better services, comfort and safety. As such, when the sharing-based transportation services appeared and offered better services in terms of comfort and safety to the users, for examples, they are more highly satisfied than the less-religious people. Despite that, there might be other reasons that need to be explored detail in further studies.

\section{CONCLUSION AND RECOMMENDATION}

The study aims to determine the demand of sharing-based transportation services in Indonesia and subsequently examine the influence of socio-religious preference on the demand. This topic is rarely touched upon by previous studies, as the sharing economy is newly implemented in Indonesia. To achieve the objectives, this study uses quantitative approach. It collects primary data from 1209 users of sharing-based transportation in Indonesia and employs Factor Analysis to derive the determinants of demand for the sharing-based transportation services. It also uses inferential statistics to examine the influence of socio-religious preference on the demand for the services.

The results show that trust, service quality and tariff are the main determinants for sharing-based transportation services in Indonesia. It was also found that there is a different preference between users in religious group and less religious groups. Religious consumers are more concerned about environment compared to the counterpart. However, in other aspects, no significant difference was found between the two groups. Overall, the study is expected to provide more insights for relevant stakeholders such as providers of sharing-based transportation services and government. It is also hoped to trigger more discussions regarding the influence of socioreligious preference for such demand and on Islamic consumer behaviour in general.

\section{REFERENCES}

[1] Allport, Gordon W. and Ross, J. Michael. (1967), Personal religious orientation and prejudice. Journal of Personality and Social Psychology 5 432-43.

[2] Chia, Jean. (2016). Shaping Policy for the Sharing Economy. Lee Kuan Yew School of Public Policy at the National University of Singapore.

[3] Darvyri, Panagiota.,et al. (2014). The Revised Intrinsic/Extrinsic Religious Orientation Scale in a Sample of Attica's Inhabitants. Psychology, 2014, 5, 1557-1567

[4] Furqani, Hafas. (2015). Individual and society in an Islamic ethical framework: Exploring key terminologies and the micro-foundations of Islamic economics. Humanomics, Vol. 31 Issue: 1,pp.74-87,

[5] Harish, Aghnia G. dan Wardhana, Aditya. (2015). Analisis Faktor-Faktor Pembentuk Preferensi Konsumen Go-Jek di Kota Jakarta.Fakultas Komunikasi dan Bisnis, Universitas Telkom

[6] Hwang, Jiyoung. and Griffiths, Merlyn. (2017). Share more, drive less: Millennials value perception and behavioral intent in using collaborative consumption services. Journal of Consumer Marketing, Vol. 34 Issue: 2, pp.132-146

[7] Kasali, Rhenald. 2017. Dirruption. PT Gramedia Pustaka Utama, Jakarta

[8] Malhotra, N.K. (2010). Marketing Research: An Applied Orientation (6th ed.). New Jersey: Prentice Hall.

[9] Mohlmann, Mareike. (2015). Collaborative consumption: determinants of satisfaction and the likelihood of using a sharing economy option again. Journal of Consumer Behaviour, J. Consumer Behav. 14: 193-207

[10] Nasscom. (2015). The Rise of the Sharing Economy: The Indian Landscape.

[11] Natyari, Shafaira G., dan Mahir, Pradana. (2016). Determinants Forming Uber Consumers' Preferences in Bandung City, Indonesia. International Journal of Emerging Technologies in Engineering Research (IJETER) Volume 4, Issue 12, December 2016

[12] Nguyen, Hong Ngoc. (2016). Customer Value in Sharing Economy: The Case of Airbnb. University of Tampee, School of Management

[13] Teubner, Timm., Hawlitschek, Florian., and Gimpel, Henner. (2016). Motives in the Sharing Economy: An Empirical Investigation of Drivers and Impediments of Peer-to-Peer Sharing

[14] Widianti, Tri. et al.(2015). Factors influencing the behavioral intention of public transport passengers. International Journal of Quality \& Reliability Management, Vol. 32 Issue: 7,pp. 666-692

[15] S. Yang, Y. Song, S. Chen. and X. Xia (2017). Why are customers loyal in sharing-economy services? A relational benefits perspective. Journal of Services Marketing, Vol. 31(1), pp. $48-62$ 